\title{
CONCEPTIONS \\ OF LAND RECLAMATION IN THE POLISH OPENCAST MINING
}

\author{
Tadeusz Chrzan, Henryk Greinert \\ Technical University of Gora; Dept.of Environment Restoration; \\ Zielona Gora, 65 - 246 \\ 50 , Podgorna str., Poland
}

In the paper the influence of surface mining on the environment is presented. The sizes of mining areas and depression funnels has been shown. Also are presented the amount of cover materials and the quantity of water pumped out from the mines in five regions of brown coal mining in Poland.

Various conceptions of land reclamation are discussed, from the method of pioneer vegetation in the years of 1950 - 1970, trough selective excavation of the humus soil in the years $1970-1980$, to conception of the direct introduction of the final type of vegetation.

In the lost part of the paper three models of agricultural land remediation are discussed, as well as the yields of the cultivated plants on recultivated former mining areas.

\section{INTRODUCTION}

In the years 1950 - 1960 the mineral rock materials open-pits mines were small and because that their interference in the each elements of the natural environment was not so big (consider to their character and scale of changes). The biggest one from these changes referred to the water relations disturbance and landscape changes, caused by digged out excavations and wastes and cover materials coning. In many cases, in spite of the less of conscious activity, fast following natural succession has cover mine-exploitation's damages. Only the building of the big brown-coal open-pits in the years $1960-1980$, with the deepness to 
$60 \mathrm{~m}$, which required a cover materials removal in amounts to $20 \mathrm{mIn} \mathrm{m}^{3}$ per year and storing these materials caused, that the influence of the brown coal mining on the environment was very big and some effects of this influence have a long-term character. Sweeping changes are observed in terrain morphology and landscape, natural conditions and terrain's utilization. The most visible for the outside observer are the changes connected with deposit work-out - the big empty excavation and cover material dump.

The additional negative factor for the agricultural - forestal cultivation also causing less of water in the intakes and wells is the rock mass drainage (of the grounds and rocks under and upper the coal bed).

The areas under open-casts are using for the making of excavation, dump areas and mine's back-up facilities. The using of the terrain is time-limited and against payment. It is including the time needed for cover material remove, coal output, after-exploitation areas recultivation and delivery of the area to the commune (territorial division) or selling for the individual farmers. The recultivation is leaded in agricultural-, forestal- or water-development direction.

The duty of the mine during recultivation works is restoration of hydrographical and communication systems. Because of this, that all of the mine-gruonds are bought, is taken as a rule that the amount of bought terrain hectares shall be equal with hectares arnount of the terrains delivered to the communes or sold after recultivation.

In the table 1 are collected the areas occupied by brown coal mines (in hectares). From the table it appears, that almost half of the occupied terrains by mines is already recultivated and delivered to the other users.

To make it possible to realize the mine working, the ground water level is drawed down by the drainage wells, what caused the creation of depression funnel around the mine. The depression funnel's size is depended from filtration coefficient of the aquifers. At present the depression funnel's size [2] expressed in ha amounts for the mines:

Adämów 20,0 tys. ha

Bełchatów 63,0 tys. ha

Konin 35,2 tys. ha

Turów: 2,5 tys. ha 
Table 1

Territorial balance of the areas occupied by brown coal mines (2) on the 01.01.1995.

\begin{tabular}{|c|r|r|r|r|}
\hline Mine & \multicolumn{4}{|c|}{ Area (ha) } \\
\cline { 2 - 5 } & $\begin{array}{c}\text { occupied from } \\
\text { the beginning } \\
\text { of mine } \\
\text { existence }\end{array}$ & $\begin{array}{c}\text { recultivated } \\
\text { and delivered } \\
\text { to the other } \\
\text { users }\end{array}$ & $\begin{array}{c}\text { under } \\
\text { exploitation }\end{array}$ & $\begin{array}{c}\text { after } \\
\text { exploitation - } \\
\text { and } \\
\text { recultivation- } \\
\text { ending }\end{array}$ \\
\hline Adamów & 4260 & 2117 & 1214 & 280 \\
\hline Bełchatów & 6339 & 2085 & 2684 & 230 \\
\hline Konin & 8257 & 4015 & 2664 & 832 \\
\hline Turów & 4753 & 850 & 3803 & 34 \\
\hline TOTAL & 23609 & 9067 & 10365 & 1376 \\
\hline
\end{tabular}

On the area like this is following the vanishing of the water in the shallow farmers wells in the villages. The mines have builded at theirs own charge about $2050 \mathrm{~km}$ of water-pipe network [4] and 65 water intakes.

On the area depression funnel is also noticed decrease of the grasses and corns yields, but it is referred to the $10 \%$ of funnel's area.

\section{CHARACTERISTICS OF THE POLISH BROWN-COAL OPEN-PITS}

The open-pit brown coal exploitation is localized in Poland in four regions, and is leaded through following national firms:

1) Konin mine with 4 open-casts, winding efficiency about $14 \mathrm{mln} \mathrm{Mg} /$ year, fuel supply for Konin power station with $583 \mathrm{MW}$ plant rating and Pątnowo power station with $1200 \mathrm{MW}$ plant rating. Characteristics of the Konin-mine open-costs are shown in table 2.

From the table appears the necessary of the developing as soon as possible not only cover materials dumping areas, but also terminal excavations of brown-coal open-costs. 
Table 2

Open - casts characteristics [3]

\begin{tabular}{|l|c|c|c|c|c|}
\hline & Unit & Patnów & Kazimierz & Jóźwin & Lubstów \\
\hline Building's beginning & year & 1957 & 1962 & 1965 & 1979 \\
\hline $\begin{array}{l}\text { Delivering to the } \\
\text { exploitation }\end{array}$ & year & 1962 & 1965 & 1971 & 1982 \\
\hline Exploitation's ending & year & 2000 & 1997 & 1999 & 2007 \\
\hline Developed reserves & $\operatorname{mln} \mathrm{Mg}$ & 17,7 & 4,2 & 18,3 & 64,6 \\
\hline Overlay thickness & $\min \mathrm{Mg}$ & 50,5 & 47,5 & 47,9 & 46,1 \\
\hline Coal bed thickness & $\mathrm{m} \ln \mathrm{Mg}$ & 8,8 & 6,6 & 9,0 & 28,8 \\
\hline Sulphur content & $\%$ & 0,9 & 1,2 & 0,7 & 0,4 \\
\hline Coal uptake & $\mathrm{m} \ln \mathrm{Mg}$ & 3,2 & 1,7 & 2,9 & 5,6 \\
\hline Stripings remove & $\mathrm{m} \ln \mathrm{m}^{3}$ & 17,0 & 8,2 & 24,0 & 6,0 \\
\hline Excaivation's deepness & $\mathrm{m}$ & 59,3 & 54,1 & 56,9 & 74,9 \\
\hline
\end{tabular}

In the table are shown the average values.

2) Adamów-mine with 3 open-casts: Władysławów, Adamów and Koźmin, winding efficiency about $5 \mathrm{mln} \mathrm{Mg}$ /year. Fuel supply for Adamów power station with $600 \mathrm{MW}$ plant rating. Developed reserves are about $120 \mathrm{mln} \mathrm{Mg}$.

3) Turów-mine with 1 open-cast, winding efficiency about $15 \mathrm{mln} \mathrm{Mg}$ /year. Fuel supply for Turow power station with $2000 \mathrm{MW}$ plant rating. Developed reserves are about $568 \mathrm{mln} \mathrm{Mg}$.

4) Bełchatów mine with open-cast, winding efficiency $38,5 \mathrm{mln} \mathrm{Mg} / \mathrm{year}$. Fuel supply for Bełchatów power station with $4320 \mathrm{MW}$ plant rating. Developed reserves are about $568 \mathrm{mln} \mathrm{Mg}$.

The mines mentioned above in 1994 have been taking up the coal and removing the cover material in amount, which are shown in the table 3.

From the table appears, that enormous amounts of the stripping needs dumping process and next recultivation in agricultural or forestry direction. 
Table 3

The productivity indices of the mines $1,2,3,4$

\begin{tabular}{|l|l|r|r|r|r|r|}
\hline Specification & Unit & 1 & 2 & 3 & 4 & Total \\
\hline Coal uptake & tys. $\mathrm{Mg}$ & 13380 & 4772 & 14852 & 33650 & 66654 \\
\hline Strippings remove & tys. $\mathrm{m}^{3}$ & 74170 & 34212 & 45497 & 99740 & 253619 \\
\hline Water pumping & tys. $\mathrm{m}^{3}$ & 96525 & 76851 & 22539 & 192822 & 388737 \\
\hline El. energy consumtion & $\mathrm{MWh}$ & 344717 & 162466 & 490495 & 757605 & 1755243 \\
\hline
\end{tabular}

\section{RECULTIVATION CONCEPTIONS FORMATION IN POLAND (1)}

In 1953 the Polish Academy of Science (PAN) has brought into being the Scientifical Committee for Upper-Silesia Industrial Region (GOP), which have been engaged in natural environment degradation's scale recognition and in degradation process inhibit-methods elaborating.

In 1961, in connection with rising up the importance of ecological problems, instead of Committee was created the Department of Scientifical Researches of Upper-Silesia Industrial Region of Polish Academy of Science in Zabrze-city, which next in 1970 has changed the name in the Department of Industrial of Industrial Areas Environment Restoration of Polish Ac. of Sc. During this period the recultivation's problems were for the first time serious elaborated, specially natural environment formation in regions with mining industry, which produced the big amounts of wastes and translocated the enormous amounts of ground masses.

In 1970 was created in the Konin-mine the Research Station of Polish Ac. of Sc., which finally was converted in the Department of Recultivation of Agricultural Academy in Poznań.

Their task was the elaboration and practical application of biological methods of recultivation of the after-mining areas at a lowest charge. 


\section{1. CONCEPTION OF THE TECHNICAL RE-CREATION OF THE SOILS (1)}

The author of this conception was Prof. Świętochowski from Wrockaw. He says, that only one and effective solution, which makes possible to restoration of after-mines areas with dumped rocks from cover layers, is selective dumping of the soil's humus horizon and after exploitation covering with this material the barren rocks on the dumps. The costs connected with this recultivation technology amounts in this period about $1000 \mathrm{q}$ of rye per hectare. The author excluded the possibility of returning dumping, barren grounds for the agricultural utilization.

Prof. Świętochowski says, that afforestation of the incoherently formed areas after deposit's exploitation with open-pit method will be enough big attainment.

This conception was right for the recultivation of the wastes and dumping areas of the firmrocks open-pits, where soil is not presented, but only rock fractions with different mechanical composition. It would not refer to the brown coal open-pits, where we can cover the dumped cover material with clays.

However selective dumping of the humus horizon of the soil for the fertilizing of the barren grounds excavating during exploitation of the all arts deposits and big industrial building is included to the polish law regulations and is in force in Poland till now.

\section{2. CONCEPTION OF THE PIONEER PLANTS (1)}

The author of this conception was Prof. Skawina from Kraków. He says, that quality of humus horizons, which are located upper the brown-coal deposits, in compare with chernozems is very low, so collected of these humic grounds for the dumps fertilizing is groundless and very expensive.

He admits as more rational the covering of dumping areas with covering rocks layer more suitable for the future soil formation. In described time period the selective getting of this layer costs $1600-2300 \mathrm{q}$ of the corn per ha, what has limiting use of this method.

For the decrease of costs, author has elaborated the conception of pioneer plants for two directions of after-mining areas use - agricultural 
and forestal. As the main purpose of the biological transformation, he appreciates rock-ground transformation into soil with lowest valuation class. This transformation of after-mining grounds properties in the soil direction is following as a result of pioneer plants growing, mainly Melilot, or afforestation with False Acacia, Black Alder and Gray Alder.

The transformation process takes 4 to 7 years for the agricultural recultivation direction and 10 to 15 years for the forestal recultivation direction. After this period the aplantation reconstruction is needed, which consist in the replacement of pioneer plants with economically useful plants.

He admits, that this recultivation method is cheapest and minimal arduous for the mines. It has an effect in National Commission of Surface Protection against Mine-Damages decision, that main recultivation direction in Poland should be the forestal one.

The dumps afforestation is making in Belchatów- and Tarnówmines on the outer-dumps.

\section{3. CONCEPTION OF FINAL APLANTATION (1)}

The professor's Skawina conception has leaded the recultivation process to the one engineer-agrotechnical treatment. But, as Prof. Bender admits the main-point of the recultivation process lies not in the treatment, but in biogenic processes. According to the Bender thesises, recultivation is a "organized joint action of abiotic and biotic factors, which making possible in a short time and at the lowest charge, creation from rock-ground the productive soil".

The biochemical transformations, which are occurred in the dumped rock, are under the anthropogenical influence. The Prof. Bender's conception lies on the following rules, using:

1 - correctly making mining works connected with slopes and top-areas of the dumps forming and the dumps themselves, and hydrogeological net of after-mining area forming;

2 - creation of the right conditions for the plants growing or afforestation, through rock-ground chemizm renovation with mineral fertilizers using; 3 - renovation of the after-mining grounds physical conditions, as a result of mechanical cultivation, which has stimulated the rock weathering processes;

4 - including of the flora to the soil-creation process and soil productivity formation. 


\section{RESULTS OF THE FINAL APLANTATION CONCEPTION USING (1)}

On the experimental fields, where the soil's chemizm renovation was not done, the corn yields are not exceed $0,3 \mathrm{Mg} / \mathrm{ha}$.

On the fields, after mineral fertilization the rape yields, a early as in the first year amounts (in average) $2,5 \mathrm{Mg} / \mathrm{ha}$ and the wheat yields 3,0 $\mathrm{Mg} / \mathrm{ha}$. These yields are higher, than average yields obtained on the other soils near the mine:

For the agricultural development of the dumps: top-areas 3 recultivation models are worked out:

a) rape-corn - consist in the alternating growing of rape and wheat,

b) feed - consist in the 5-years growing of lucerne with grasses, and next

2-years growing of wheat,

c) lucerne - many-years lucerne growing.

On the dumps slopes after making all works, as for the agricultural development, are planted maple, great maple, ash, oak, larch, beech.

The ground chemizm renovation is leaded first 4 years from the aplantation beginning, and plants density is increased to the 5000 trees per hectare and 2500 shrubs per hectare. This amount of the trees and bushes secured effective protection of the slopes surface against water erosion and good wood-production.

\section{SUGGESTIONS}

1. The technical soils restoration conception and the pioneer plants conception are right, when recultivation of the dumps and excavations of the rock row-materials open-pits is leaded.

2. The final aplantation conception is a good method of cover material dumps and terminal excavations in the brown coal open-pits, where the top layer of the soil can be created from the clay material. 


\section{LITERATURE}

1. Bender J. Ocena skuteczności rekultywacji terenów poeksploatacyjnych $\mathrm{w}$ gómictwie odkrywkowym: Konferencja VI Krajowy Zjazd Górnictwa Odkrywkowego. - Konin, 1995.

2. Czapla Z. Rola węgla brunatnego w gospodarce polskiej: Konferencja VI Krajowy Zjazd Górnictwa Odkrywkowego. - Konin, 1995.

3. Gach S. i inni. Eksploatacja węgla brunatnego a ochrona środowiska w kopalni "Konin". - Kleczew, 1995.

4. Uberman R. i inni. Górnictwo odkrywkowe w strategii ekorozwoju kraju: Konferencja VI Krajowy Zjazd Górnictwa Odkrywkowego. Konin, 1995. 